\title{
HORMONE-ASSOCIATED METABOLIC DISORDERS OF THE ORAL CAVITY ORGANS IN WOMEN OF REPRODUCTIVE AGE*
}

\author{
G. I. Khodorovskyi ${ }^{1}$, L. V. Panina ${ }^{2}$, T. S. Shchurko ${ }^{2}$ \\ ${ }^{1}$ Bukovinian State Medical University, Chernivtsy, Ukraine \\ ${ }^{2}$ Danylo Halytsky Lviv National Medical University, Lviv, Ukraine \\ hodorovskijgeorgij38@gmail.com
}

Oral health during pregnancy has long been a focus of interest, as there is the old wives' tale of "the loss of a tooth for every pregnancy". Special attention has been paid to the relationship between the oral cavity organs and the reproductive ones. Since the 1960s, growing scientific evidence has suggested that periodontal health is associated with pregnancy. It was supposed in the 1970s that the increase in serum estrogen and progesterone had an effect on the periodontium throughout pregnancy and correlated with clinical signs $[1,2]$.

The exact mechanisms for the onset of the greater gingival inflammation during pregnancy were not clearly described for a long time. Since the 1970s the obvious increase in circulating levels of estrogen and progesterone has been considered to have a dramatic effect on the periodontium throughout pregnancy.

During pregnancy both of them are elevated due to continuous production by corpus luteum at the beginning and the placenta afterward. By the end of the third trimester of pregnancy progesterone and estrogen reach the peak which is 10 and 30 times the levels observed during the menstrual cycle [3]. The physiological effect of estrogen on gingiva was also observed in animal models [4]. The gingiva recovered clinically when estradiol was added. The results indicate that estrogen profoundly affects physiologic events in the gingiva, including cellular proliferation and differentiation, either directly or indirectly. It is clear that endogenous sex steroid hormones play significant roles in modulating the periodontal tissues responses [5].

The results demonstrated that estrogen reduced down regulation of cytokines. In vitro study by Lappetal showed that sex hormones had an inhibitory effect on the secretion of interleukin (IL-6) production by human gingival fibroblasts (GFs). It has the potential to contribute to periodontal disease progression during pregnancy [6].

Stimulation with both estradiol and progesterone in a dose-dependent manner significantly enhanced the production of interleukin- 6 (IL-6) and IL-8 by human GFs [7, 8].

\footnotetext{
* Institution, which financed the research: Ministry of Education and Science of Ukraine.

The authors guarantee responsibility for everything published in the article, as well as the absence of a conflict of interest and their own financial interest in performing the work and writing an article.

The manuscript was received by the editorial staff 09.08.2021.
} 
Researchers prove that changes in periodontal conditions may be associated with variations in sex hormones [9]. It is very well demonstrated by G. N. Güncü et al. in the review, where the effects of endogenous sex hormones on the periodontium are described. They conclude that sex steroid hormones play significant role modulating periodontal tissues responses. Changes in periodontal conditions may be associated with variation of sex hormones. Progesterone level in blood increases from the second week of the menstrual cycle, and drops prior to menstruation [10]. Progesterone is associated with increased permeability of the microvasculature altering the rate and the pattern of collagen production in the gingiva [10]. It increases folate metabolism [11, 12], stimulates the production of prostaglandins and enhances the chemotaxis of polymorphonuclear leukocytes [13]. As a result, significant gingival inflammatory changes have been documented in association with menstrual cycle, and gingival inflammation seems to be aggravated by an imbalance or increase in sex hormones [14]. Bleeding and a swollen gingiva, as well as increase in gingival exudate can be observed [15].

As it has been noted above, increased level of estrogen and progesterone is linked to various periodontal pathologies. That is due to estrogen and progesterone receptors in the gingiva. Moreover, due to that, gingival tissue exhibits receptors for such hormones. Gingiva is considered as a target organ for their direct action [16, 17]. These hormones might act on gingival cells by changing the effectiveness of the epithelial barrier to bacterial injury or by affecting the collagen maintenance and repair. Localization of estrogen receptor (ER) and progesterone receptor (PgR) has been reported in the human periodontium, demonstrating that periodontal tissues are the target tissues for these hormones [18].

It has been reported that receptor for sex hormones is present in different periodontal tissues. Progesterone receptors in cultured human gingival fibroblasts are characterized by intracellular localization [19]. Estrogen receptor $B$ is in periodontal ligament cells, as well as in oral epithelium and salivary glands [20,21].

Estrogen regulates DNA synthesis in human gingival epithelial cells, and periodon- tal ligament $[22,23]$. It has been shown that progesterone modulates the proliferation and differentiation of human periodontal ligament cells [24].

The research showed that over the course of the menstrual cycle in women, salivary antioxidant capacity was significantly lower than during the follicular phase in the women with periodontitis. The study concluded that the menstrual cycle is associated with the gingival inflammation and discomfort [25].

Indian Researchers of Laxmi Bai Institute of Periodontology in review article discussed the influence of sex hormones on both healthy and ill oral tissue [26]. Hormones have both direct and indirect effects on oral health and they also influence their susceptibility to periodontal disease [27]. Steroid sex hormones (androgens, estrogens and progesterone) affect cellular growth, proliferation and differentiation in target tissues including keratinocytes and fibroblasts in the gingiva [5]. The researchers collected saliva directly from the parotid gland into a small plastic vial [28]. Those specimens were obtained from normal men and women gingival fluid. It was drown into a micropipette by capillary action. Pure parotid saliva was obtained by placing a modified CarlsonCrittenden cup over the opening of Stensen's Duct. The study examined the relation between saliva flow rate and salivary steroids concentration, as well as relation between concentrations in serum and saliva.

Testosterone receptors are found in the periodontal tissues including the number of fibroblasts. Testosterone affects periodontal tissues by increasing matrix synthesis. It regulates interleukin-6 (IL-6) expression by oral fibroblasts and modulates IL-6 production by gingival fibroblasts in vitro [29,30]. Testosterone inhibits prostaglandins formation by human gingival connective tissue. It was shown in experiments on human gingival homogenate treated with different concentrations of testosterone. The results indicate that testosterone, at the dose levels tested, has inhibitory effect to the cyclooxygenase pathway of arachidonic acid metabolism in the gingiva [31].

Ribeiro with colleagues [32] demonstrated the role of testosterone in the formation of teeth. Investigation of both primary and per- 
manent tooth sizes in females from oppositesex dizygotic (DZOS) twin pair compared with females from dizygotic same-sex (DZSS) and monozygotic (MZ) twin pairs indicate the influence of intrauterine male hormone, including the initial testosterone surge, on dental development. There was significantly larger crown size in DZOS females in both dentitions, with the crown height dimensions displaying the greatest increase in size. It is concluded that the growth-promoting effects of the Y chromosome and intrauterine male hormone levels influence different tooth dimensions and contribute differentially to the sexual dimorphism of human teeth.

In the recent few decades saliva attained a sovereign status of a bodily fluid worthy of scientific exploration. Some researchers consider saliva to be a "mirror to the body» [33]. The clinical usefulness of measuring steroids in saliva has received much more attention [34, 35, 36].

Special emphasis is made on the sex steroid hormones: female (estrogen, estrogen-estriol, progesterone) and male (testosterone, dehydroepiandrosterone) hormones. For a long time there was little discussion of the route by which steroids (or other hormones) enter saliva. At the same time there was no hypothesis as to why some hormones can be found in saliva, while others cannot. A number of carefully performed studies give examples of important physiological hormonal activity in saliva. Such steroids as androgens act as pheromones in olfactory communication of various mammalian species, e.g. facilitating mating behavior in swine or serving as odor for rodent nestling. Salivary peptide hormones, such as epidermal growth factor (EGF) and transforming growth factor-alpha (TGF-alpha) and amines such as melatonin are involved in the regulation of inflammatory processes and in the promotion of cell proliferation. They also contribute to rapid wound healing in the oropharyngeal epithelium and allow for involvement of salivary cytokines, such as interleukin-8 and leptin, in thermogenesis in the oral cavity and the salivary glands. Assessment of salivary hormone profiles may provide promising targets for diagnostic tumor markers [37].

Some links between sex hormones in saliva and reproductive success are studied by a num- ber of researchers. Helen Fisher is a biological anthropologist, a Senior Research Fellow at the Kinsey Institute and a member of the Center for Human Evolutionary Studies at Rutgers University. According to her, there is evidence that saliva in men includes testosterone and that a man kisses a woman with the more open mouth [38]. Further H. Fisher comes to the conclusion that men, when kissing women, unconsciously are trying to transfer testosterone to stimulate sex drive in women.

For research and clinical practice it is very important to know the route by which hormones enter into saliva. Vinning R. F. et al examined the entry mode of various hormones into saliva [39]. The results suggest that the lipid-soluble unconjugated steroids (cortisol, estriol, testosterone, progesterone, etc.) enter saliva predominantly via the intracellular route; their salivary concentration is not dependent on saliva flow rate. It approximates their unbound concentration in plasma. Accordingly, the salivary concentration of these hormones may provide a useful clinical index of unbound hormones concentration in plasma.

The conjugated steroids, which are essentially lipid insoluble (dehydroepiandrosterone sulfate (DHEAS), conjugated estrogens, are largely excluded from saliva, although small amounts do enter via the 'tight junctions' (ultrafiltration) between the acinar cells, and their concentration in saliva is highly flow-rate dependent. The researchers conclude that the salivary concentration of unconjugated steroids may usefully reflect the concentration of free (nonprotein-bound) steroids in plasma.

Recent decades evidence indicated that oral epithelial cells and fibroblasts constitutively expressed ghrelin mRNA. Hormone ghrelin was initially isolated from gastric mucosa. Later it was found to be widely expressed in different tissues such as kidneys, intestines, and pancreas [40]. In the oral cavity ghrelin was detected in human saliva, salivary glands, oral epithelial cells, gingival crevicular fluid (GCF) and cells in the lamina propria of periodontium [40].

Ghrelin is a 28-amino-acid acylated peptide hormone. It is the ligand to the G-proteincoupled growth hormone secretagogue receptor (GHS-R) which is expressed in the brain and in various peripheral tissues in two GHS-R 1a 
and $1 \mathrm{~b}$. It is shown that ghrelin and both receptors are produced by the human salivary glands [41], oral keratinocytes and gingival fibroblasts [41], as well as the expression of both cognate receptors in oral epithelial cell and fibroblasts [40].

Ghrelin - orexigenic hormone - plays a major role in the gastrointestinal tract. It is also responsible for the metabolic response to starvation by modulating insulin secretion, glucose metabolism and amino acid uptake [36].Ghrelin is found in salivary gland and saliva gingival crevicular fluid (GCF) and gingival tissues; ghrelin mRNA and GHSR (Growth hormone secretagogue receptor) is detected in human oral epithelial cells and gingival epithelial cells and fibroblasts in the lamina propria. It is suggested that ghrelin produced in the oral cavity plays a regulatory role in innate immune responses to inflammatory infection [40]. Ghrelin exerts functions through its functional receptor GHS-R1a [42].

An alternative variant of the growth hormone receptor (GHR) subtype, termed GHS$\mathrm{R} 1 \mathrm{G}$, is found, although it is not activated by synthetic GHSR or ghrelin and is unclear whether it is a functional receptor [43].

Ghrelin receptor (GHS-R1a) is distributed in several structures of the brain of mammalian species [44, 45, 46, 47]. But GHS-R1a is mainly expressed in the pituitary. It is also present in the thyroid pancreas, adrenal gland, spleen, myocardium, ovary, and testis [48].

Ghrelin activities, as a hormone, depend entirely on acylation and are mediated by GHSR-1a. The des-acyl ghrelin does not bind to GHSR-1a. Different negative feedbacks of GHS-R1a are described as for ghrelin binding to its receptor [49]. Ghrelin binds to GHS-R1a and leads to intracellular calcium concentration [50].

Further GHS-R1a increases intracellular cAMP, which is the second messenger that activates the subsequent signaling cascade. These results indicate that epithelial cells can elicit intracellular signals in response to ghrelin, possibly via ligation to GHS-R1a [40].

For the last few decades several experiments suggested that ghrelin could act as a modulator of the male and female reproductive functions. In vivo and in vitro studies showed that ghrelin was able to exert its action at dif- ferent levels of the hypothalamic-pituitarygonadal axis. The hypothalamus is identified as the main source of ghrelin in the central nervous system. GHS-R1a receptor mRNA is found in many areas of the brain [51]. In rats, systemic administration of ghrelin reduces in vivo the GnRN (Gonadotropin-Releasing Hormone) pulse frequency. NPY (neuropeptide $\mathrm{Y})$ is involved in demediation of the effects of ghrelin on pulsatile GnRH secretion [52].

The study establishes that ghrelin suppresses LH and FSH secretion in males and females [53]. An effect in females depends on the period of estrous cycle. Ghrelin did not affect FSH (follicle stimulating hormone) secretion in the proestrus and estrus periods in gonadectomized male and female rats after single injection [54]. In women during menstrual cycle, administration of ghrelin did not affect basal and $\mathrm{GnRH}$ (gonadotropin releasing hormone) induced Lh and FSH secretion [55].

1) It is concluded that effects of ghrelin on LH and FSH secretion suggest that peptide plays a key role in the reproductive functions.

2) Beside central actions on the reproductive functions, some evidence indicates that ghrelin could exert direct effects on the female and male gonads.

Ghrelin was demonstrated in rodents and sheep in Leydig cells [56].

In the human normal testis in Leydig and Sertoli cells, ghrelin is apparently linked to the degree of cell differentiation, but that is not characteristic for germ cells [57]. But in adult sheep testis, ghrelin is evident in Leydig and Sertoli cells, as well as germ cells during the mitotic phases and meiotic prophases of the spermatogenic cycle [58]. Intratesticular injection of ghrelin in adult rats inhibited mRNA expression of gene encoding stem cell factor (SCR). It is a Sertoli cell product and a key signal for germ cell production, a putative regulator of Leydig cell development and a survival factor for the spermatogonia in adult rats [59]. Thus, the actions of ghrelin on tubular SCF mRNA could have an impact on the regulation of spermatogenesis and also on Leydig cell proliferation [51].

Ghrelin significantly inhibits in a dose-dependent manner both hCG (human chorionic 
gonadotropin) and cAMP-stimulated testosterone release by Leydig cells [56]. This inhibitory effect of ghrelin on testosterone secretion is associated with decrease in the hCG-stimulated expression levels of the mRNAs. The effects of ghrelin on testosterone plasma levels in rats depend on nutritional state. Researchers used two groups of rats. In fad rats, ghrelin administration induces a slight decrease in testis mass without detectable changes in testosterone plasma level. In chronic food restricted rats, where ghrelin level is known to be increased, administration of ghrelin induces decrease in plasma testosterone. Thus, high levels of ghrelin could contribute to male reproductive axis alterations in situations of energy deficit [60].

Ghrelin affects morphometrical and intracellular changes in ovaries and embryo development. Chronic administration of ghrelin decreases the mean diameter of follicles, the number of corpora lutea, the diameter of the theca layer and the whole ovarian volume in the female rats [61].

Ghrelin produces direct control of ovarian function. It affects not only folliculogenesis but steroidogenesis as well. It has inhibitory effect on production of progesterone and takes place either in the absence or in the presence of hCG by acting through its functional GHSR1a estradiol in cultured granulosa luteal cells $[62,63]$. The present in vitro study provides the first evidence of the direct inhibitory influence of ghrelin on human luteal function.

There are studies which showed that ghrelin was able to exert its action at different levels of the hypothalamic-pituitary-gonadal axis. In rats and humans ghrelin inhibits $\mathrm{Lh}$ and FSH secretion in males and females [64].

In mammalian species, ghrelin treatment inhibits gonadotropin releasing hormone (GnRH) LH and FSH secretion at the hypothalamic and pituitary levels. In female rats, injection of ghrelin decreases FSH only in the metestrus but does not affect FSH secretion in the proestrus and estrus periods of the estrous cycle. In women during the menstrual cycle, ghrelin administration did not affect basal and GnRHstimulated LH and FSH secretion [65, 66]. It is proven that ghrelin affects embryo development. It inhibits the development of mouse preimplantation embryos in vitro [67]. Authors demonstrated the presence of ghrelin and GHR $\mathrm{m}$ RNA in mouse oocytes and preimplantation embryos, and GHR and GHS-R mRNAs were expressed in mouse morula, Blastocyst, and hatched blastocysts stage embryos. It is noted that ghrelin is a novel placental-derived hormone [68] that plays an important role in rat fetal development. But the effects of ghrelin on the development of the embryo are still not clear [51].

In summary the following conclusions may be drawn from an extensive literature. The literature describing mechanisms linking the two groups of organs (oral cavity and reproductive) suggests a functional relationship between organs of oral cavity and reproductive organs. Sex steroid (female and male) hormones affect the structure and functions of salivary glands, periodontium and mucus membrane of oral cavity. All of them contain constitutively functional steroid receptors alpha(a) and beta (B).

Fluctuating levels of sex hormones during puberty, menses, pregnancy and menopause have direct and indirect effects on oral health. Androgens, estrogens and progesterone show effects of cellular growth, proliferation and differentiation in target tissues (keratinocytes in the gingiva and salivary glands).

Oral cavity organs, in turn, affect the reproductive ones. Groups of researchers reported that salivary glands, oral keratinocytes and gingival fibroblasts produce and secrete hormone ghrelin, which is present in human saliva in higher concentrations compared with the blood plasma. Concentration of ghrelin found in gingival crevicular fluid (GCF) was approximately 500-fold higher that detected in saliva [40].

Ghrelin is able to exert its actions on physiological functions at different levels of the hypothalamic-pituitary gonadal axis. Ghrelin mediates endocrine activities by GHSR-1a, - the growth hormone secretagogue receptor. That receptor is mainly expressed in the pituitary and also present in the adrenal gland, ovary and testis. Beside central actions on the reproductive functions ghrelin exerts direct effects on the female and male gonads. In females ghrelin affects follicular genesis. In males it also regulates germ cell production. Ghrelin exerts an inhibitory effect on steroidogenesis 
and through its various biological functions including energy metabolism by promoting fat deposition and food intake could be a key signal between energy status and control of fertility.

Besides hormones there are neuroreflectory links between the oral cavity and reproductive organs. Experiments on rats demonstrate that tooth movement up regulates production of relaxin by ovaries. Results of that study suggest that mechanical irritation of tissues in the periodontium (orthodontic manipulation) may affect relaxin expression in the ovary. Authors have not discussed the mechanism of that reaction. We think that the gingivo-ovarian reflex is similar to the eye-cardio Danini-Ashner reflex. On the other hand, there is extensive literature regarding the association of polycystic ovary syndrome (PCOS) and other systemic conditions including periodontal disease.

Last but not least, currently accepted periodontal diseases classification recognizes the influence of endogenously produced sex hormones on the periodontium.

\section{REFERENCES}

1. Min Wu, Shao-Wu Chen, Shao-Yun Jiang. Mediators of inflammation 2015; 11.

2. Min Wu, Shao Wu Chen, Wei Lan Su, Hong-Ying Zhu. Mediators of inflammation 2016; 6 .

3. Zachariasen RD. Women and Health 1993;20(2): 21-30.

4. Reynolds MA, Aberdeen GW, Pepe GI, et al. $J$ Periodontol 2004;75(5): 693-701.

5. Güncü GN, Tözüm TF, Çaglayan F. Australian Dental J 2005;50(3):138-145.

6. Yokoyama D, Hinode K, Masuda M, Yoshioka D. Oral Microbiol Immunol 2005;20(4): 239-243.

7. Miyagi M, Morishita M, Iwamoto Y. J Periodontol 1993; 64(1): 1075-1078.

8. Morishita M, Miyagi M, Iwamoto Y. J Periodontol 1999; 70(7): 557-760.

9. Plancak D, Visher B, Jordic-Srdjak K, Slaj K. Coll Antropol 1998;22(Suppl): 51-55.

10. Ottomo-Corgel J, Steinberg BJ. Periodontal medicine and the female patients, Hamilton, 2000: 151-167.

11. Pack ARC, Thomson ME. J Clin Periodontol 1980;7: 402-414.

12. Thomson ME, Pack ARC. J Clin Periodontol 1982;9: 275-280.

13. Mlyagi M, Aoyoma H, Morishita M. Iwamoto Y. J Periodontol 1992;63: 28-32.

14. Holm-Pederson P, Loe H. J Periodontal Res 1967;2: 13-20.

15. Saxen J. Clin Genet 1984;25: 232-335.

16. Hosseni FA, Tirgarri F, Shaigan S. Iran J Public Healt 2006;35: 38-41.

17. Markou E, Eleana B, Lazarrous T, Antonios K. Open Dent J 2009;3: 114-119.

18. Vivek MR, Hernandez EJ, Wenk SC. J Clin Endocrinol Metabol 1982;54(3): 608-612.

19. Kawahara K, Shimazu A. J Periodontal Res 2003;38(3): 242-246.
20. Jőnsson D, Anderson G, Ekblad M, et al. Arch Oral Biol 2007;52(7): 669-676.

21. Välimaa H, Savolainen S, Soukka T. J Endocrinol 2004; 180(1): 55-62.

22. Nebel D, Bratthall G, Ekblad E, et al. J Periodontal Res 2011; 46(5): 622-628.

23. Jönson D, Wahlin A, Idvall I, et al. J Periodontal Res 2005;40(5): 401-406.

24. Yuan G, Cai C, Dai D. Calcified Tissue Internat 2010; 87(2): 158-167.

25. Kawamoto A, Sugano N, Matohashi I, Matsumoto S. J Periodontal Res 2012;47(5): 593-598.

26. Nirola A, Batra P. J Int Clin Dent 2018;10: 3-11.

27. Deepa MS. IJWDC 2013;1: 15-20

28. Vining F, McGinley A, Rice BV. J Clin Endocrinol Metab 1983;58: 454.

29. Parkar M, Tabona P, Newman H, Alsen I. Cytokine 1998; 10(8): 613-619

30. Gornstein RA, Lapp CA, Bustos-Valdes SM, Zamorano P. J Periodont 1999;70(6): 604-609.

31. Tawfik MA, Elattarhsien S, Lin Daniel E. Leukotrienes Med 1982;9(1): 25-34.

32. Ribeiro DC, Brook AH, Hughes TE, et al. J Dent Res 2013;92(5): 425-431.

33. Schipper RG, Silletti E, Vingerhoeds MH. Arch Oral Biol 2007;52: 1114-1135.

34. Riad-Fahmy D, Read GF, Walker RF, Griffiths K. Endocr Rev 1982;3: 367-395.

35. Vining Ross F, Robynne Mc Ginley, Richard G. Symons. Clin Chem 1983;29(10): 1752-1756.

36. Zolotukhin S. Oral Dis 2013;19(3): 219-229.

37. Grőschi M. Bioessays 2009;31(8): 843-852.

38. Fisher HE. Anatomy of love: a natural history of mating, marriage, and why we stray, New York, 2017: 464 p. 
39. Vining RF, Mc Gienley RA, Symons RG. Clin Chem 1983;29(10): 1752-1756.

40. Ohta K, Laborde NJ, Kajiya M, et al. J Dent Res 2011;90(11): 1286-1292.

41. Groshe M, Topf HG, Bohlender J, et al. Clin Chem 2005;51: 997-1000.

42. Tropea A, Tibery F, Minici F, et al. J Clin Endocrinol Metab 2007;92(8): 3239-3245.

43. Leung PK, Chow KBS, Lan PN. Cell Signalling 2007; 19(5): 1011-1022.

44. Geelissen SME, Back IME, Darras VM, et al. General Comp Endocrinol 2003;134(2): 167-174.

45. Tanaka M, Miyazaki T, Yamamoto I, et al. General Comp Endocrinol 2003;134(2): 198-202.

46. Saito ES, Kelya H, Toshibana T, et al. Regulatory Peptides 2005;125(1-3): 201-208.

47. Richards MP, Poch SM, Mc Murtry JP. General Comp Endocrinol 2006;145(3): 298-310.

48. Granapavan S, Kola B, Bustin SA, et al. J Clin Endocrinol Metab 2002;87(6): 2988-2991.

49. Lugue RM, Park S, Peng XD, et al. J Mol Endocrinol 2004;32(2): 437-448.

50. Kojima M, Hosoda H, Date Y, et al. Nature 1999;402: 656-660.

51. Dupont J, Maillard V, Coyral-Castel S, et al. Int J Peptides 2010;8.

52. Lebrethon MC, Aganina A, Fournier M, et al. J Neuroendocrinol 2007;19(3): 181-188.

53. Vulliemoz NR, Xiao E, Xia-Zhang I, et al. Endocrinology 2008;149(3): 869-874.
54. Lafranko I, Bonelli M, Baldi M, et al. J Clin Endocrinol Metab 2008;93(9): 3633-3639.

55. Messini CI, Dafopoulos K, Chalvatras N, et al. Human Reprod 2009;24(4): 976-981.

56. Tena-Sempere M, Bareiro MI, Gonzales LC, et al. Endocrinology 2002;143(2): 717-725.

57. Gaytan, Barreiro MIC, Caminos JE, et al. J Clin Endocrinol Metab 2004;89(1): 400-409.

58. Millen DW, Harrison JI, Brown YA, et al. Reprod Biol Endocrinol 2005;3 (article 60).

59. Garcia MC, Lopez M, Alvares CV, et al. J Reprod 2007; 133(3): 531-540.

60. Sirotkin AV, Chrenkova M, Nitrayova S, et al. Peptides 2008;29(8): 1362-1368.

61. Kheradmand A, Roshangar I, Taati M, Sirotkin AV. Tissue Cell 2009;41(5): 311-317.

62. Viami I, Vottero A, Tassi F, et al. J Clin Endocrinol Metab 2008;93(4): 1476-1481.

63. Tropea A, Tiberi F, Minici F, et al. J Clin Endocrinol Metab 2007;92(8): 3239-3245.

64. Vulliemoz NR, Xiao E, Xia-Zhang I, et al. J Endocrinol 2008;149(3): 869-874.

65. Messini CI, Dafopoulos K, Chalvatzas N, et al. Human Reprod 2009;24(4): 976-981.

66. Lafranko F, Bonelli I, Baldi M, et al. J Clin Endocrinol Metab 2008;93(9): 3633-3639.

67. Kawamura K, Sato N, Fukuda J, et al. J Endocrinol 2003;144(6): 2623-2633.

68. Gualillo O, Caminos J, Blanko M, et al. J Endocrinol 2001;142: 788-794. 


\title{
HORMONE-ASSOCIATED METABOLIC DISORDERS OF THE ORAL CAVITY ORGANS IN WOMEN OF REPRODUCTIVE AGE
}

\author{
G. I. Khodorovskyi ${ }^{1}$, L. V. Panina ${ }^{2}$, T. S. Shchurko ${ }^{2}$ \\ ${ }^{1}$ Bukovinian State Medical University, Chernivtsy, Ukraine \\ ${ }^{2}$ Danylo Halytsky Lviv National Medical University, Lviv, Ukraine \\ hodorovskijgeorgij38@gmail.com
}

There is emerging evidence of a possible relationship between the oral cavity and reproductive organs. Recent studies suggest these functional relations. The aim of this review was to synthesize the available evidence on this relationship. Clinical observation established that sex hormones enhance gingival inflammation in periodontal healthy women during pregnancy and that periodontal condition is associated with variation of sex hormones in blood. Estrogen regulates DNA synthesis in human gingival epithelial cells and periodontal ligament, estrogen reduces down regulation of cytokines. Estrogen and progesterone affect the periodontium via appropriate receptors (estrogen receptor and progesterone receptor). They are localized in human periodontium, demonstrating that periodontal tissues are the target tissues for these hormones.

Testosterone receptors are found in the periodontal tissues. It inhibits prostaglandin secretion and reduces interleukin production. At the same time testosterone stimulates osteoblast proliferation and differentiation, also enhances matrix synthesis by fibroblast, osteoblasts, and periodontal ligament. The role of testosterone in the formation of teeth is demonstrated in the paper.

In females and males, in saliva there are sex steroid hormones. The results suggest that lipid soluble unconjugated steroids (estriol, testosterone, progesterone) enter saliva via intracellular route; the conjugated steroids (lipid insoluble (dehydroepiandrosterone, conjugated estrogens)) enter via the 'tight junctions' between the acinar cells. Recent evidence indicates that organs of the oral cavity (salivary glands, periodontal tissues, oral epithelial cells mucus) produce ghrelin-hormone which affects organs of the reproductive system directly or indirectly via hypothalamic-pituitary-gonadal axis. In all these organs, there is an appropriate receptor. In conclusion, the organs of oral cavity and organs of reproductive system are functionally linked by sex steroid hormones and ghrelin, besides that periodont can influence ovaries by neuro-reflectory link.

Key words: oral cavity organs, reproductive organs, sex hormones, ghrelin, saliva.

\section{ГОРМОНАЛЬНО АСОЦІЙОВАНІ МЕТАБОЛІЧНІ ПОРУШЕННЯ ОРГАНІВ РОТОВОЇ ПОРОЖНИНИ У ЖІНОК РЕПРОДУКТИВНОГО ВІКУ}

\author{
Ходоровський Г. І. ${ }^{1}$, Паніна Л. В. ${ }^{2}$, Щурко Т. С. ${ }^{2}$ \\ ${ }^{1}$ Буковинський державний медичний університет, м. Чернівиі, Украйна; \\ 2 Львівський національний медичний університет імені Данила Галицького, \\ м. Львів, Україна \\ hodorovskijgeorgij38@gmail.com
}

З'являються нові докази можливого функціонального зв'язку між ротовою порожниною та репродуктивними органами. Метою цього огляду було синтезувати наявні докази цих взаємовідносин. Клінічні спостереження встановили, що статеві гормони підсилюють запалення ясен у пародонтологічно здорових жінок під час вагітності, і що стан пародонту пов'язаний із зміною статевих гормонів у крові. Естроген регулюе синтез ДНК в епітеліальних клітинах ясен і пародонті, зменшує регуляцію цитокінів. Естроген і прогестерон впливають на пародонт через відповідні рецептори, які локалізовані в пародонті людини, демонструючи, що тканини пародонту є тканинами-мішенями для цих гормонів. Рецептори тестостерону також знаходяться в тканинах пародонта. Він пригнічуе секрецію простагландинів і зменшує вироблення інтерлейкінів. У той же час тестостерон стимулює проліферацію та диференціацію остеобластів, а також посилюе синтез матриксу фібробластами, остеобластами та періодонтальною зв'язкою. У статті продемонстровано роль тестостерону у формуванні зубів.

У жінок і чоловіків у слині є статеві стероїдні гормони. Результати свідчать про те, що ліпідорозчинні некон'юговані стероїди (естріол, тестостерон, прогестерон) проникають у слину внутрішньоклітинним шляхом; кон'юговані стероїди (нерозчинні в ліпідах (дегідроепіандростерон, кон'юговані естрогени)) надходять через «щільні з’еднання» між ацинарними клітинами. Останні дані свідчать про те, що органи ротової порожнини (слинні залози, тканини пародонта, слизові клітини ротової порожнини) виробляють гормон грелін, який прямо чи опосередковано впливає на органи репродуктивної системи через вісь гіпоталамус-гіпофіз-гонади. У всіх цих органах є відповідний рецептор. Як висновок, органи ротової порожнини та органи репродуктивної системи функціонально пов'язані між собою статевими стероїдними гормонами та греліном, крім того, пародонт може впливати на яєчники завдяки нервово-рефлекторному ланцюгу.

Ключові слова: органи ротової порожнини, репродуктивні органи, статеві гормони, грелін, слина. 